\title{
Hubungan Kadar Low Density Lipoprotein Dengan Gangguan Pendengaran Sensorineural
}

\author{
${ }^{1}$ Nurfadhilah Amini Nasution \\ ${ }^{2}$ Muhammad Edy Syahputra Nasution \\ ${ }^{2}$ Siti Masliana Siregar \\ ${ }^{3}$ Des Suryani
}

\begin{abstract}
${ }^{1}$ Fakultas Kedokteran, Universitas Muhammadiyah Sumatera Utara
${ }^{2}$ Bagian Ilmu Penyakit Telinga, Hidung, dan Tenggorokan, Fakultas Kedokteran, Universitas Muhammadiyah Sumatera Utara

${ }^{3}$ Departemen Histologi, Fakultas Kedokteran, Universitas Muhammadiyah Sumatera Utara
\end{abstract}

\section{Alamat Korespondensi:}

Muhammad Edy Syahputra Nasution

Bagian Ilmu Penyakit Telinga, Hidung, dan Tenggorokan, Fakultas Kedokteran Universitas Muhammadiyah Sumatera Utara, Medan, 2020

+62823-6952-1949

Email:mhd.edysyahputra@umsu.ac.id 


\begin{abstract}
ABSTRAK
Kelainan metabolisme lipid pada hiperlipidemia merupakan penyebab terjadinya plak arterosklerosis pada telinga dalam dan saraf kranial VIII sehingga dapat menyebabkan gangguan pendengaran sensorineural. Berdasarkan penelitian sebelumnya, teori ini masih dipertanyakan. Tujuan penulisan untuk mengetahui hubungan kadar LDL dengan gangguan pendengaran sensorineural. Penelitian ini merupakan penelitian analitik dengan pendekatan cross-sectional. Sampel penelitian diambil berdasarkan rumus deskriptif kategorik dengan besar sampel 38 orang.Data yang didapat merupakan hasil dari pemeriksaan laboratorium, pemeriksaan fisik telinga, hidung, dan tenggorokan dan pemeriksaan audiometri nada murni.Penelitian ini dilakukan di RSU Haji Medan dan RS Putri Hijau TK II Medan.Jumlah subjek penelitian ditentukan dengan menggunakan teknik consecutivesampling. Data dianalisis menggunakan statistik uji chi square menujukkan hasil bahwa terdapat hubungan kadar LDL dengan gangguan pendengaran sensorineural yang signifikan dengan nilai $\mathrm{p}=0,001$.Usia terbanyak pada penelitian ini adalah usia 50-60 tahun, jenis kelamin yang terbanyak adalah perempuan, derajat gangguan pendengaran yang terbanyak adalah derajat sedang. Kesimpulan penelitian yakni terdapat hubungan yang bermakna antara Kadar LDL dengan gangguan pendengaran sensorineural.
\end{abstract}

\title{
Kata Kunci: Audiometri, Gangguan Pendengaran
}

\begin{abstract}
Abnormalities of lipid metabolism in hyperlipidemia are the cause of atherosclerotic plaque in the inner ear and cranial nerves VIII, which can cause sensorineural hearing loss. Based on previous research, this theory is still questionable. Objective: To determine the relationship of LDL levels with sensorineural hearing loss. Method: This study is an analytic study with a cross-sectional approach. The research sample was taken based on a categorical descriptive formula with a large sample of 38 people. The data obtained is the result of laboratory tests, physical examination of the ears, nose and throat and audiometry examination of pure tone. This research was conducted at Medan Haji General Hospital and Putri Hijau Hospital II Medan. The number of research subjects was determined using consecutive sampling techniques. Data were analyzed using chi square test statistics. Results: There was a significant correlation of LDL levels with sensorineural hearing loss with a value of $p=0.001$. The highest age in this study was 50-60 years of age, the most sex was female, the highest degree of hearing loss was moderateConclusion: There is a significant relationship between LDL levels with sensorineural hearing loss.
\end{abstract}

\section{Keywords: Audiometry, Hearing Loss}




\section{PENDAHULUAN}

Di era modernisasi ini dalam kehidupan sehari-hari masih banyak orang yang mengalami gangguan fungsi pendengaran. (Suresh, 2011) Kehilangan pendengaran bisa terjadi kapan saja. Onsetnya dapat terjadi secara tiba-tiba atau bertahap dan bersifat permanen atau progresif pada orang dewasa.(Blazer et al., 2016).

Berdasarkan data dari WHO tahun 2018 bahwasanya terdapat 466 juta penduduk dunia yang menderita gangguan pendengaran yang terdapat di wilayah Asia Selatan, Asia Fasifik dan wilayah Afrika Sub-Sahara dengan peningkatan prevalensinya hampir empat kali lipat. Hal ini diperkirakan secara global bahwa setiap tahun biaya gangguan pendengaran belum ditangani melebihi 750 miliar dolar internasional.(Menteri Kesehatan Republik Indonesia, 2017)

Terdapat beberapa faktor risiko yang dapat mempengaruhi pendengaran diantaranya terpapar suara keras akibat kebisingan, penggunaan perangkat musik portabel dengan cara yang tidak aman, infeksi telinga, ototoksisitas dari golongan aminoglikosida pada pengobatan tuberkulosis yang resisten terhadap obat. (Menteri Kesehatan Republik Indonesia, 2017) Gangguan pendengaran yang tidak dapat ditangani dapat mempengaruhi sosial.(Bickenbach, 2011)
Gangguan pendengaran sensorineural merupakan jenis gangguan pendengaran yang terletak pada telinga bagian dalam koklea, saraf vestibulocochlear atau pusat pemrosesan sentral otak.Fungsi koklea dapat dipengaruhi dari iskemia pembulu darah di telinga bagian dalam. Sel rambut koklea merupakan hal terpenting untuk fungsi elektromotil dan penguat koklea. Dan selaput plasma dinding lateral sel rambut luar sangat sensitif terhadap keadaan hiperlipidemia. (Gautom Handique et.al, 2016)

Kelainan metabolisme lipid pada hiperlipidemia dikenali dengan meningkatnya kadar kolesterol total, Low Density Lipoprotein (LDL), trigliserida serta menurunnya High Density Lipoprotein (HDL) melebihi dari batas normal pada lipid plasma.(Fama, 2017) Menurut Riset Kesehatan Dasar Nasional (RISKESDAS) tahun 2013 proporsi LDL sangat tinggi ( $\geq 190 \mathrm{mg} / \mathrm{dL})$ berusia diatas 15 tahun sebesar $15,9 \%$ populasi.(Indonesia, 2015) Prevalensi hiperlipidemia dengan gangguan pendengaran sensorineural sekitar 5 $38 \%$ yang dapat disebabkan dari iskemik pada Choclea.(Liu et al., 2012) Prevalensi gangguan pendengaran dengan kadar LDL yang meningkat sebesar 65,2\%.(Swaminathan A, Sambandam R, 2011) 
Apabila kadar LDL terlalu tinggi di pembuluh darah maka LDL akan teroksidasi dan menyebabkan disfungsi endotel. makrofag akan memfagositosis lipoprotein yang teroksidasi sehingga menjadi sel busa. Hal ini dapat menyebabkan terbentuknya plak aterosklerosis sehingga menyebabkan gangguan pendengaran sensorineural.(Odeh et al., 2015)

Menurut penelitian sebelumnya menyatakan bahwasanya tidak ada hubungan antara hiperlipidemia dengan gangguan pendengaran sensorineural namun berdasarkan penelitian lainnya melaporkan bahwasanya ada hubungan antara hiperlipidemia dengan gangguan pendengaran sensorineural (Odeh et al., 2015)

Berdasarkan angka terjadinya gangguan pendengaran yang semakin meningkat dan masih kontroversi antara hiperlipidemia dengan gangguan pendengaran sensorineural, maka peneliti tertarik untuk mengkaji kembali. Bagaimanakah hubungan kadar LDL dengan gangguan pendengaran sensorineural di Negara kita?

\section{METODE}

Penelitian ini merupakan penelitian analitik dengan desain cross-sectional yang dilakukan pada bulan November 2019 hingga bulan Januari 2020. Sampel penelitian diambil berdasarkan rumus deskriptif kategorik dengan besar sampel 38 orang. Penelitian ini dilakukan di RSU Haji Medan dan RS Putri Hijau TK II Medan dan pemeriksaan Audiometri dilakukan oleh PT. Kasoem Hearing Head Office Medan. Jumlah subjek penelitian ditentukan dengan menggunakan teknik consecutive sampling dengan kriteria inklusi dan kriteria ekslusi yang ditentukan oleh peneliti.

Kriteria inklusi terdiri atas: Tidak memiliki serumen, tidak memiliki riwayat gangguan pendengaran kongenital, trauma akustik, trauma kepala atau telinga, infeksi telinga, riwayat operasi telinga, penggunaan obat ototoksik seperti anti TBC, golongan aminoglikosida. Pasien laki-laki atau perempuan yang berusia 18 60 tahun. Bersedia diikut sertakan dalam penelitian dengan menandatangani informed consent. Kriteria ekslusi yaitu: merokok, pengguna statin, penyakit sistemik lain yang mempengaruhi fungsi pendengaran seperti hipertensi, diabete mellitus, sampel yang tidak mengikuti pemeriksaan hingga selesai penelitian.

Penelitian ini menggunakan data primer yang diperoleh dari anamnesis, pemeriksaaan telinga dengan otoskop, audiometri nada murni, dan data sekunder pada rekam medik. Proses pengambilan sampel dimulai dengan melihat hasil labolatorium dari data sekunder di poli penyakit dalam. Kemudian direkrut 
menjadi subjek penelitian sesuai kriteria inklusi. Pada penelitian ini subjek penelitian yang diekslusi sebesar 29 orang dan di drop out sebanyak 3 orang.

Penelitian ini sudah mendapatkan persetujuan dari komisi etik penelitian kesehatan dari institusi kami dan informed consent dari semua subjek penelitian.

Analisis data pada proporsi usia, jenis kelamin, kadar LDL, Jenis gangguan pendengaran, derajat gangguan pendegaran disajikan dalam bentuk deskriptif. Uji chisquare digunakan untuk melihat hubungan antara kadar LDL dengan gangguan pendengaran sensorineural yang disajikan dalam bentuk analisis bivariat. Dinyatakan bermakna secara statistik jika didapatkan nilai- $p<0,05$.

\section{Pemeriksaan Audiologi}

Pemeriksaan audiometri nada murni dilakukan pada semua subjek penelitian. Pemeriksaan audiometri dilakukan di ruangan yang kedap suara. Pemeriksaan audiometri nada murni dari $250 \mathrm{~Hz}$ sampai $8.000 \mathrm{~Hz}$ dengan menggunakan Audiometri AD-28 Interacoustics Clinical Audiometer (Interacoustics, Assens, Denmark). Penilaian ambang batas hantaran udara dilakukan pada frekuensi 250 hingga $8000 \mathrm{~Hz}$ dan penilaian ambang batas hantaran tulang dilakukan pada frekuensi $250 \mathrm{~Hz}$ hingga $4000 \mathrm{~Hz}$. Pengukuran dilakukan berdasarkan metode naik Hughson-Westlake, naik 5 dan turun
10.(Nasution Muhammad Edy, 2018) Menurut WHO klasifikasi derajat gangguan pendengaran berdasarkan ISO audiometri yaitu: pendengaran normal apabila $\leq 25 \mathrm{~dB}$, gangguan pendengaran derajat ringan 26-40 dB, gangguan pendengaran derajat sedang 41-60 dB, gangguan pendengaran derajat berat $61-80$ $\mathrm{dB}$ dan gangguan pendengaran derajat sangat berat $\geq 81$ dB. (World Health Organization, 2013)

Ambang pendengaran dihitung dengan nilai rata-rata $0,5-4 \mathrm{kHz}$ dalam $\mathrm{dB}$. Dinamakan gangguan pendengaran sensorineural jika hantaran udara dan hantaran tulang >25 dB.(Nasution Muhammad Edy, 2018) Subjek peneliti mengalami gangguan pendengaran apabila satu atau kedua telinganya mengalami gangguan pendengaran >25 dBHL.

\section{HASIL}

Berdasarkan dari jumlah sampel yang didapat pada penelitian ini jenis kelamin. terbanyak adalah perempuan sebanyak $23(60,52 \%)$ orang, usia terbanyak adalah usia 50-60 tahun sebanyak $16 \quad(42,10 \%)$ orang, jenis gangguan pendengaran tuli sensorineural sebanyak $18(47,36 \%)$ orang dan derajat gangguan pendengaran terbanyak adalah derajat sedang sebesar $(28,94 \%)$ orang.

Berdasarkan tabel 1. menunjukkan gangguan pendengaran terbanyak pada usia 50-59 tahun yaitu $16(42,10 \%)$ orang, 
dan jenis kelamin terbanyak pada yaitu perempuan $16(42,10 \%)$ orang.

Berdasarkan tabel 2 hasil penelitian menunjukkan hasil terbanyak pada kadar LDL > $100 \mathrm{mg} / \mathrm{dL}$ yaitu 17 (44,73\%) orang, dan derajat gangguan pendengaran terbanyak yaitu derajat sedang sebanyak $11(28,94 \%)$ orang.

Hasil penelitian dari tabel 3 menunjukkan adanya hubungan yang bermakna $(\mathrm{p}<0,05)$ antara kadar LDL yang tinggi dengan gangguan pendengaran sensorineural. Perhitungan Prevalence Ratio diperoleh dengan nilai PR sebesar 4.685 atau PR >1, bermaknakan bahwa kadar LDL merupakan faktor risiko terjadinya gangguan pendengaran sensorineural.

\section{PEMBAHASAN}

Hasil penelitian dari tabel 3 menunjukkan adanya hubungan yang bermakna $(\mathrm{p}<0,05)$ antara kadar LDL yang tinggi dengan gangguan pendengaran sensorineural. Perhitungan Prevalence Ratio diperoleh dengan nilai PR sebesar 4.685 atau PR >1, bermaknakan bahwa kadar LDL merupakan faktor risiko terjadinya gangguan pendengaran sensorineural. Hal ini sejalan dengan penelitian sebelumnya yang dilakukan oleh (Gautom Handique et.al, 2016) (Mudhol RS, 2019) (Parmar Sandip M, Khare Pushkan, 2017) menunjukkan bahwa ada korelasi profil lipid dengan gangguan pendengaran sensorineural.

Namun penelitian ini tidak sesuai dengan penelitian lain yang menyatakan bahwa tidak ada hubungan kadar LDL dengan gangguan pendengaran sensorineural. (Liu et al., 2012) (Evans et al., 2006) Hal ini disebabkan nilai hiperlipidemia tidak terlalu sering diamati dan tidak ada nilai median dari parameter lipid yang diukur. Alasan perbedaan yang diamati tidak terlalu diketahui. Namun hal ini kemungkinan terkait dengan durasi atau keparahan profil lipid yang diderita oleh subjek penelitian dengan lamanya penderita hiperlipidemia. Menurut penelitian lainnya dalam studi terdapat 40 subjek penelitian tidak menemukan hubungan antara dislipidemia dengan gangguan pendengaran sensorineural dikarenakan adanya faktor perancu.(Liu et al., 2012)(Evans et al., 2006)

Berdasarkan hasil penelitian menunjukkan hasil terbanyak pada kadar LDL > $100 \mathrm{mg} / \mathrm{dL}$ yaitu $17(44,73 \%)$ orang, dan derajat gangguan pendengaran terbanyak yaitu derajat sedang sebanyak 11 (28,94\%) orang. Dengan demikian dapat dikatakan bahwa kadar LDL yang meningkat atau $>100 \mathrm{mg} / \mathrm{dL}$ akan memberikan pengaruh terhadap gangguan pendengaran.

Peningkatan kadar LDL merupakan salah satu faktor risiko penyebab terjadinya 
aterosklerosis. LDL memiliki fungsi sebagai transportasi kolesterol dari hati melalui sistem peredaran darah untuk disimpan ke organ lain khususnya pembuluh darah arteri dan jantung. Apabila kadar LDL terlalu tinggi dapat menurunkan peran kadar HDL untuk mencegah pembentukan plak aterosklerosis di arteri. Sel rambut koklea sangat sensitif terhadap keadaan hiperlipidemia Jika kadar LDL terlalu tinggi di pembuluh darah maka LDL akan teroksidasi dan menyebabkan disfungsi endotel. Kemudian sel endotel yang teraktivasi berinteraksi dengan monosit dan chemoattractants untuk bermigrasi dan mendorong monosit ke dalam subendotel. Chemoattractants menyebabkan sel tunika otot polos bermigrasi ke intima.

Monosit berdiferensiasi menjadi makrofag. Makrofag akan memfagositosis lipoprotein yang teroksidasi sehingga menjadi sel busa. Sel busa yang terakumulasi berkontribusi terhadap pembentukan plak aterosklerosis. Pengaruh dari hiperlipidemia dapat meningkatkan permeabilitas dinding vaskular kokleayang berasal dari arteri labirin yang sensitif terhadap perubahan suplai darah. Apabila terjadinya thrombus, embolus, hipoksia atau vasospasme dapat menyebabkan berkurangnya aliran darah sehingga menyebabkan gangguan pendengaran
sensorineural.(Gautom Handique et.al, 2016) (Odeh et al., 2015).

Hasil penelitian ini menunjukkan bahwa subjek penelitian diambil mulai dari usia 18 tahun sampai 60 tahun. Setelah dilakukan penelusuran data sekunder, tidak didapatkan sampel usia dibawah 30 tahun. Hal ini kemungkinan terjadi karena jarang ditemukan peningkatan profil lipid pada usia muda. Namun penelitian ini tidak sesuai dengan RISKESDAS tahun 2013 yang menyatakan bahwa gangguan profil lipid sudah terjadi diatas 15 tahun.(Indonesia, 2015)

Kelompok usia terbanyak pada penelitian ini adalah usia 50-59 tahun sebanyak $16(42,10 \%)$ orang. Hal ini menunjukkan bahwa semakin tinggi usia akan semakin meningkatkan risiko terjadinya gangguan pendengaran. Insiden gangguan pendengaran akan meningkat sejalan dengan usia. pertambahan usia pada manusia akan meningkatkan kemungkinan terjadinya degenerasi yang semakin tinggi sehingga fungsinya akan menurun termasuk pada organ pendengaran. Khususnya pada telinga bagian dalam, terjadi perubahan pada bagian sensor saraf, pembuluh darah, jaringan penunjang maupun sinaps saraf. Organ corti merupakan bagian dari koklea yang paling rentan terhadap perubahan akibat proses degenerasi yang biasa terjadi pada sel-sel rambut luar. 
Hasil ini sejalan dengan penelitian sebelumnya yang menyatakan bahwa rerata usia yang paling tinggi menunjukkan rentang usia 50 - 60 tahun.(Mudhol RS, 2019)(Parmar Sandip M, Khare Pushkan, 2017)(Simpson et al., 2013) Hasil penelitian ini sesuai dengan teori yang menyatakan bahwa gangguan pendengaran akibat usia disebabkan dari degenerasi fisiologis akibat penuaan serta akumulasi dari paparan kebisingan yang terjadi dan kondisi medis seperti hiperlipidemia yang perlahan-lahan akan progresif mengurangi sensitivitas pendengaran danpemahaman bicara dilingkungan yang bising, melambatnya pusat pemrosesan informasi akustik, dan gangguan lokalisasi sumber suara. Hiperlipidemia merupakan salah satu faktor risiko terhadap gangguan pendengaran. Gangguan pendengaran terkait usia merupakan salah satu kondisi kesehatan kronis yang mempengaruhi individu lebih dari 50 tahun.

Hasil penelitian berdasarkan dari jumlah sampel yang didapat pada penelitian ini jenis kelamin. terbanyak adalah perempuan sebanyak $23(60,52 \%)$ orang, jenis gangguan pendengaran tuli sensorineural sebanyak 18 (47,36\%) orang dan derajat gangguan pendengaran terbanyak adalah derajat sedang sebesar $(28,94 \%)$ orang. Hal ini dikarenakan bahwa kadar LDL meningkat lebih banyak pada wanita saat menopause sedangkan pada pria kadar LDL meningkat saat usia paruh baya.(Mešalić et al., 2008) Menopause terjadi pada perempuan berusia diatas 50 tahun walaupun usia menopause bervariasi. Peningkatan kadar LDL merupakan faktor risiko terbentuknya plak aterosklerosis. Menopause didefinisikan sebagai penghentian menstruasi untuk jangka waktu lebih dari satu tahun yang dimulai dengan perubahan fungsi ovarium. Saat terjadinya menopause menyebabkan kadar LDL mengalami peningkatan dan kadar HDL menurun. Ovarium mengalami perubahan hormon pada produksi estradiol dan progesteron. Estradiol dibentuk oleh konversi dari estrone dan sekresi hormon pertumbuhan menurun setelah usia 40 tahun. Hal ini sejalan dengan penelitian sebelumnya dari salah satu studi bahwasanya peneliti tidak menemukan tingkat gangguan pendengaran dengan jenis kelamin.(Liu et al., 2012)

Penelitian ini menunjukkan bahwa derajat gangguan pendengaran terbanyak adalah derajat sedang sebanyak 5 orang, kemudian disusul dengan derajat ringan sebanyak 11 orang dan derajat terendah adalah derajat berat sebanyak 2 orang. Hal ini sesuai dengan penelitian yang dilakukan sebelumnya menunjukkan bahwa gangguan pendengaran terbanyak adalah derajat sedang dengan nilai rata-rata keseluruhan sebesar 128 \pm 9.7.(Gautom Handique et.al, 2016) Menurut penelitian 
lainnya mereka menemukan korelasi antara kadar LDL dengan derajat gangguan pendengaran dengan nilai rata-rata keseluruhan sebesar $185.33 \pm 20.32$.

Bagi orang dengan gangguan pendengaran sedang, percakapan yang dilakukan dengan jarak 1 meter sudah tidak dapat didengar dengan baik meskipun dalam kondisi sepi. Namun, pada frekuensi tertentu ia masih dapat mendengar bunyibunyian hanya saja dengan intensitas suara yang lebih keras dari biasanya.

Masalah gangguan pendengaran harus segera ditangani. Apabila tidak dan terlalu lama ditangani akan berdampak pada kesehatan dan kebugaran, baik fisik maupun psikologis. Sebab, gangguan pendengaran bukan hanya masalah mengenai tidak mendengar tentang suara, tapi juga mengenai mengolah kata dan suara di dalam otak untuk memahami pesan tersebut yang menyebabkan otak terus berfikir dan sibuk. Jika tidak ada kata-kata yang masuk dalam waktu lama akan membuat otak tidak mengenali lagi kata-kata dan pesan tersebut.

\section{KESIMPULAN DAN SARAN}

Penelitian ini didapatkan hubungan antara kadar LDL dengan gangguan pendengaran sensorineural. Penelitian ini hanya melakukan pengukuran variabel sebanyak satu kali sehingga sulit untuk menentukan hubungan sebab dan akibat antara kadar LDL dengan gangguan pendengaran sensorineural secara pasti dan jelas. Diperlukan penelitian lebih lanjut dengan jumlah sampel pasien yang lebih besar, dengan menggunakan studi kohort dalam penelitian yang lebih luas untuk memperkecil terjadinya bias sehingga dapat memperkuat kesimpulan yang didapat dari penelitian. Dan diperlukan pemeriksaan rutin dan penyuluhan kesehatan telinga untuk mencegah komplikasi yang disebabkan profil lipid yang terlalu tinggi.

\section{DAFTAR PUSTAKA}

Bickenbach, J. (2011). The world report on disability. Disability \& Society, 26(5), 655-658.

Blazer, D. G., Domnitz, S., \& Liverman, C. T. (2016). Hearing health care for adults: Priorities for improving access and affordability. In Hearing Health Care for Adults: Priorities for Improving Access and Affordability. Washington DC. https://doi.org/10.17226/23446

Evans, M. B., Tonini, R., Do Shope, C., Oghalai, J. S., Jerger, J. F., Insull Jr, W., \& Brownell, W. E. (2006). Dyslipidemia and auditory function. Otology \& Neurotology: Official

Publication of the American Otological Society, American Neurotology Society [and] European Academy of Otology and 
Neurotology, 27(5), 609.

Fama, M. A. (2017). Pengaruh Pemberian

Air Tebu Hitam terhadap Kadar

Low-Density Lipoprotein (LDL).

Buletin Farmatera, 2(3), 146-152.

Gautom Handique et.al. (2016). A Study of

Serum Lipid Profile in Clinically

Diagnosed patient of sensorineural

Hearing Loss. International Journal

of Advanced Research (IJAR).,

Volume 4 (9) :1571-1576. 2016.

doi:10.21474/IJAR01/1611

Indonesia, P. E. (2015). Pengelolaan dan

pencegahan diabetes melitus tipe 2 di Indonesia. $\mathrm{Pb}$. Perkeni.

Liu, M., Alafris, A., Longo, A. J., \& Cohen, H. (2012). Irreversible atorvastatin-associated hearing loss. Pharmacotherapy: The Journal of Human Pharmacology and Drug

Therapy, 32(2), e27-e34.

Menteri Kesehatan Republik Indonesia. (2017). Rencana Strategi Nasional Penanggulangan Gangguan Pendengaran dan Ketulian Untuk Mencapai Sound Hearing 2030.

Mešalić, L., Tupković, E., Kendić, S., \& Balić, D. (2008). Correlation between hormonal and lipid status in women in menopause. Bosnian Journal of Basic Medical Sciences, 8(2), 188.

Mudhol RS, P. A. . (2019). Lipid Profile in Patients with Sensorineural Hearing
Loss - One Year Observational Study in a Tertiary Care

Centre.Department of ENT and HNS, Jawaharlal Nehru Medical College KAHER, Belagavi, Karnataka, India. 4(1):77-80(doi:10.18689/mjol1000116).

Nasution Muhammad Edy, H. T. S. H. (2018). The Effects of Rheumatoid Arthritis in Hearing Loss: Preliminary Report. Journal of Clinical and Diagnostic Research March [Cited: 2018 Apr 23];12:MC01-MC05.

Odeh, O. I., Kuti, M. A., Fasunla, A. J., \& Nwaorgu, O. G. (2015).

Sensorineural hearing loss and dyslipidemia: is there any relationship. West Afr J Med, 34, 2731.

Parmar Sandip M, Khare Pushkan, C. M. (2017). Evaluation of effects of diabetes mellitus type 2 and hyperlipidemia on hearing. Indian Journal of Otology. Wolters KlomerMedkom., 23,(July-September).

Simpson, A. N., Matthews, L. J., \& Dubno, J. R. (2013). Lipid and C-reactive protein levels as risk factors for hearing loss in older adults. Otolaryngology--Head and Neck Surgery, 148(4), 664-670.

Suresh, K. P. (2011). An overview of randomization techniques: an 
unbiased assessment of outcome in clinical research. Journal of Human Reproductive Sciences, 4(1), 8.

Swaminathan A, Sambandam R, B. M.

(2011). Evaluation of the auditory

effects of hyperlipidaemia and

diabetes mellitus by using

audiometry. Journal Clinical and

Diagnostic Research, volume 5 (8),

Desember: 1528-1532. 2011

World Health Organization. (2013).

Prevention of blindness and deafness

of hearing impairment. 
Tabel 1. Distribusi frekuensi Kadar LDL berdasarkan usia, jenis kelamin.

\begin{tabular}{lccc}
\hline \multicolumn{1}{c}{ Variabel } & $\begin{array}{c}\text { Kadar } \mathbf{L D L}<\mathbf{1 0 0} \\
\mathbf{m g} / \mathbf{d L}\end{array}$ & $\begin{array}{c}\text { Kadar } \mathbf{L D L}\rangle \\
\mathbf{1 0 0} \mathbf{~ m g} / \mathbf{d L}\end{array}$ & Total \\
& $\mathbf{n}(\boldsymbol{\%})$ & $\mathbf{n}(\boldsymbol{\%})$ & \\
\hline Usia & $9(23,68)$ & $1(2,63)$ & 10 \\
30-39 Tahun & $6(15,78)$ & $6(15,78)$ & 12 \\
40-49 Tahun & $0(0)$ & $16(42,10)$ & 16 \\
50-60 Tahun & & & \\
Jenis Kelamin & $6(15,78)$ & $9(23,68)$ & 15 \\
Laki-laki & $7(18,42)$ & $16(42,10)$ & 23 \\
Perempuan & & & \\
\hline
\end{tabular}

Tabel 2. Distribusi frekuensi jenis dan derajat gangguan pendengaran

\begin{tabular}{lccc}
\hline \multicolumn{1}{c}{ Variabel } & $\begin{array}{c}\text { Kadar } \mathbf{~} \mathbf{D L}<\mathbf{1 0 0} \\
\mathbf{m g} / \mathbf{d L}\end{array}$ & $\begin{array}{c}\text { Kadar } \mathbf{L D L}>\mathbf{1 0 0} \\
\mathbf{m g} / \mathbf{d L}\end{array}$ & Total \\
& $\mathbf{n}(\boldsymbol{\%})$ & $\mathbf{n}(\boldsymbol{\%})$ & \\
\hline $\begin{array}{l}\text { Tuli Sensorineural } \\
\text { Tidak }\end{array}$ & $13(34,21)$ & $7(18,42)$ & 20 \\
Ya & $1(2,63)$ & $17(44,73)$ & 18 \\
Derajat Gangguan & & & \\
Pendengaran & $1(2,63)$ & $4(10,52)$ & 5 \\
Tuli Ringan & $0(0)$ & $11(28,94)$ & 11 \\
Tuli Sedang & $0(0)$ & $2(5,26)$ & 2 \\
Tuli Berat & & & \\
\hline
\end{tabular}


Tabel 3. Hubungan Penderita Kadar LDL dengan Gangguan Pendengaran Sensorineural

\begin{tabular}{|c|c|c|c|c|}
\hline \multirow{3}{*}{ Kelompok } & \multicolumn{2}{|c|}{$\begin{array}{l}\text { Gangguan } \\
\text { Pendengaran } \\
\text { Sensorineural }\end{array}$} & \multirow{3}{*}{$p$ value $^{a}$} & \multirow{3}{*}{$\begin{array}{c}\text { PR } \\
(95 \% \mathrm{Cl})\end{array}$} \\
\hline & Ya & Tidak & & \\
\hline & n & $\mathbf{n}$ & & \\
\hline $\begin{array}{c}\text { Kadar LDL > } \\
100 \text { mg/dL }\end{array}$ & 17 & 7 & & \\
\hline $\begin{array}{c}\text { Kadar LDL < } \\
100 \mathrm{mg} / \mathrm{dL}\end{array}$ & 1 & 13 & $0,001^{b}$ & 4.685 \\
\hline
\end{tabular}

Ket $={ }^{\text {a }}$ Berdasarkan uji Chi square

${ }^{\mathrm{b}}$ Bermakna secara statistic 